\title{
Barbarie en plural: percepciones del indígena en el auge cauchero boliviano
}

Barbarism in the plural: perceptions of the Indian in the Bolivian rubber boom Barbarie au pluriel : perceptions de l'Indien à l'ère du caoutchouc en Bolivie

Lorena I. Córdoba

\section{OpenEdition}

\section{Journals}

Edición electrónica

URL: https://journals.openedition.org/jsa/14384

DOI: $10.4000 /$ jsa. 14384

ISSN: 1957-7842

Editor

Société des américanistes

Edición impresa

Fecha de publicación: 31 diciembre 2015

Paginación: 173-202

ISSN: 0037-9174

Referencia electrónica

Lorena I. Córdoba, «Barbarie en plural: percepciones del indígena en el auge cauchero boliviano», Journal de la Société des américanistes [En línea], 101-1 et 2 | 2015, Publicado el 15 marzo 2016, consultado el 24 febrero 2023. URL: http://journals.openedition.org/jsa/14384 ; DOI: https://doi.org/ $10.4000 / j s a .14384$ 


\title{
Barbarie en plural: percepciones del indígena en el auge cauchero boliviano
}

\author{
Lorena I. CóRDOBA
}

\begin{abstract}
Se analiza la construcción de los diferentes discursos, miradas y representaciones en torno de los indígenas de la región amazónica boliviana durante el boom del caucho. Desde fines del siglo XIX hasta las primeras décadas del siglo Xx, las sociedades indígenas de esa zona mantuvieron relaciones ambivalentes (comercio, alianza, enfrentamientos bélicos) con el frente colonizador. Sin embargo, las imágenes y representaciones sobre ellas no fueron estables ni homogéneas, puesto que araonas, cavineños, pacaguaras, caripunas y chacobos fueron estereotipados de diversas maneras por sus observadores. [Palabras clave: Amazonía boliviana, indígenas, representaciones, caucho.]
\end{abstract}

Barbarism in the plural: perceptions of the Indian in the Bolivian rubber boom. The paper analyses the construction of discourses, views and representations about the indigenous societies of Bolivian Amazonia during the rubber boom. From the final decades of the 19th century to the beginnings of the 20th, the vernacular societies held ambivalent relations with the colonization forces (commerce, alliance, armed clashes, etc.). Nevertheless, the images and representations about them were neither stable nor homogeneous, because the Araona, Cavineño, Pacaguara, Caripuna and Chacobo were stereotyped in different ways by their observers. [Key words: Bolivian Amazonia, Indians, representations, rubber boom.]

Barbarie au pluriel : perceptions de l'Indien à l'ère du caoutchouc en Bolivie. Ce texte analyse la construction des différentes représentations, images et discours forgés sur les Indiens de l'Amazonie bolivienne au cours du boum du caoutchouc. De la fin du $\mathrm{XIX}^{\mathrm{e}}$ siècle jusqu'aux premières décennies du $\mathrm{Xx}^{\mathrm{e}}$ siècle, les sociétés indiennes de la région ont maintenu des relations ambivalentes (commerce, alliance, affrontements belliqueux) avec le front colonisateur. Cependant, leurs images et leurs représentations ne furent ni stables ni homogènes : Araona, Cavineño, Pacaguara, Caripuna et Chacobo ont donné lieu à des stéréotypes différents. [Mots-clés : Amazonie bolivienne, Indiens, représentations, caoutchouc.]

* Conicet, Universidad de Buenos Aires, Argentina [lorecordoba@gmail.com]. 
El indio es naturalmente suspicaz y receloso, pérfido y vengativo, profesa una inclinación invencible hacia el vagabundaje y ama su libertad.

(Pando 1897, p. 96)

Sin indios no hay industria del caucho.

(Nordenskiöld 2003 [1922], p. 124)

En la Amazonía boliviana, el auge cauchero comienza a principios de la década de 1870 y se extiende hasta los últimos años de la década de 1910 . Se trata de un hecho social total en el sentido más literal del término; un dato estructurante, decisivo para la historia y la geografía del Oriente boliviano. E1 boom se emplaza sobre una maquinaria preexistente. Desde la década de 1860 , en efecto, gran parte de los mismos actores hasta entonces consagrados a la quina o « cascarilla » (Cinchona calisaya) comienzan a emplear los circuitos logísticos, los capitales y hasta los mismos escenarios naturales para comercializar la goma, recurso abundante en el norte boliviano, especialmente en el llamado « Territorio de Colonias » situado en la frontera entre las actuales repúblicas de Bolivia, Brasil y Perú ${ }^{1}$. Utilizando la red fluvial para la tarea de extracción y exportación, la industria cauchera se despliega velozmente a través de los ríos Madre de Dios, Beni, Purús y Madera, entre otros.

El inédito potencial económico de la industria provoca a la vez una oleada de viajes y expediciones que recorren un territorio inhóspito, apenas mencionado de forma marginal en tiempos coloniales, para el cual el relevamiento cartográfico e hidrográfico se vuelve imperativo: Lardner Gibbon, Ivon Heath o Agustín Palacios son algunas de las figuras prestigiosas comisionadas por los gobiernos de turno para hacer de punta de lanza de la colonización. Es que, ligada con la industria gomera, tenemos la variable nacionalista: la fiebre del caucho es indisociable del proceso de conformación republicana de las fronteras limítrofes, que en una de sus vertientes desencadena la guerra del Acre entre Bolivia y Brasil (1899-1903). En ese lapso transcurren también las fundaciones de las principales ciudades del norte (Riberalta, Villa Bella, etc.), la repartición de títulos de propiedad, el establecimiento sistemático de tributos fiscales o la apertura regional a una nueva economía de exportación. Lo que interesa destacar, pues, es que en todos sus niveles y en todas sus dimensiones es imposible pensar la conformación histórica del Oriente boliviano sin tomar en cuenta sus conexiones con esta actividad extractiva (García Jordán 2001)².

1. Utilizaremos como sinónimos los términos « caucho », « goma » o « siringa » más allá de sus diferencias técnicas; de hecho, vale notar que la forma de extracción y los modos de recolección del « caucho» (Castilla elastica) y la « goma» (Hevea Brasiliensis), así como sus diversos subproductos, difieren sustancialmente. Para una descripción más pormenorizada, ver Barham y Coomes 1994, p. 45 y ss.

2. Para mayores detalles sobre el auge cauchero en Bolivia, ver Fifer 1970; Roca 2001; Van Valen 2003, 2013; Gamarra Téllez 2007; Vallvé 2010; Córdoba 2012a; Guiteras Mombiola 2012. 


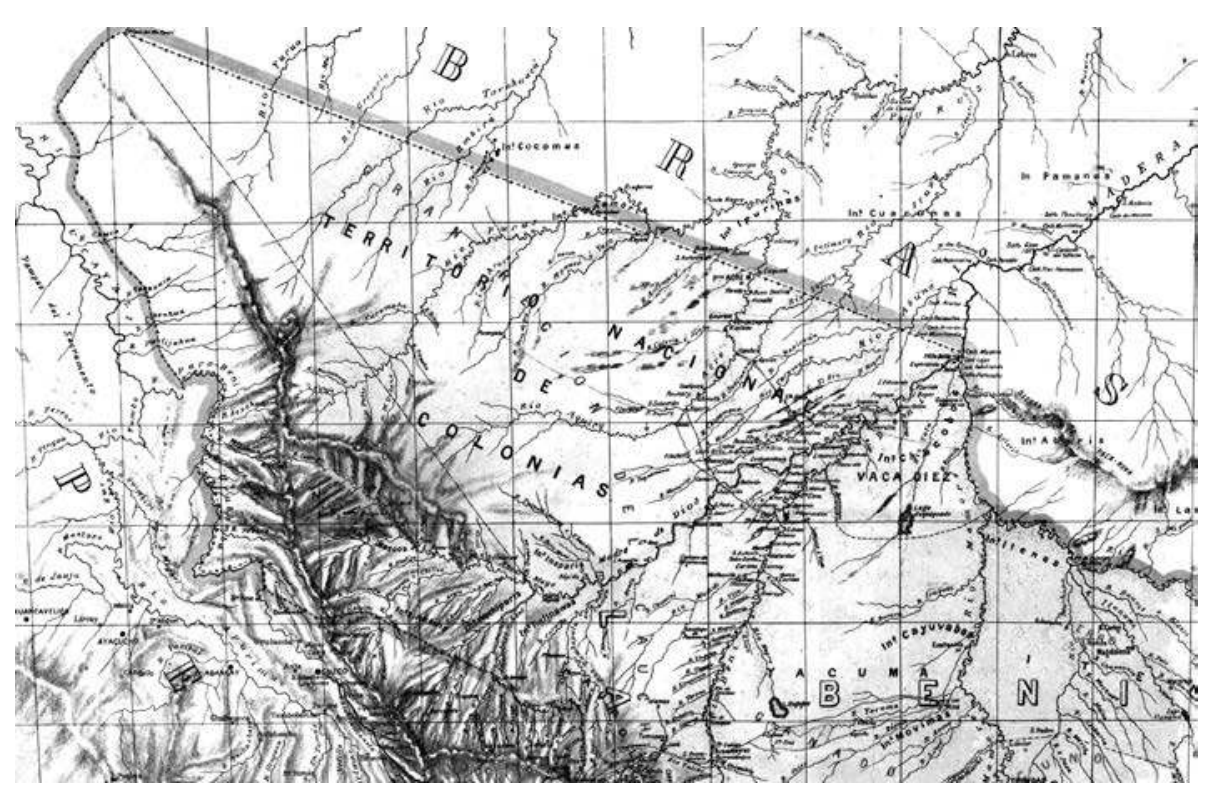

Fig. 1 - « Mapa de Bolivia levantado por el Ing. Luis García Mesa en 1904 ».

Fuente: Instituto Geográfico Militar de Bolivia³.

Sobre este telón de fondo, la industria gomífera se despliega a través de la red fluvial articulando una estructura ramificada, troncal, que con pequeñas variaciones locales se repite en casi todos los países de la cuenca amazónica 4 . El circuito básico puede resumirse así: un patrón o « habilitador » adelanta mercadería a cuenta a un gomero o siringuero, a quien se asigna un « centro » o « colocación » (campamento donde podrá explotar varias « estradas » o vías de árboles gomeros que se rayan diariamente para colectar la leche) ${ }^{5}$. Luego de un tiempo, el gomero transporta la producción obtenida a la « barraca », « casa aviadora » o « siringal », sede del habilitador, auténtico locus sociológico de

3. En este mapa puede ubicarse la gran mayoría de los grupos étnicos mencionados en el texto, así como los principales ríos, puertos y localidades.

4. La metáfora arbórea trasciende el campo específico de la industria gomífera, y de hecho sirve para repensar el funcionamiento de otras modalidades extractivas del período tanto en los Andes (minería) como en el Chaco (ingenios azucareros) (Richard 2013).

5. En Bolivia se utiliza como sinónimo la palabra « cauchero » para denominar a todo aquel que se dedica a extraer caucho o goma; en Brasil ocurre lo mismo con el término « seringueiro » o « seringalista ». En Perú, en cambio, existe una diferencia lexical pues se denomina shiringa a la goma elástica, siendo « siringuero » el que se dedica a la misma y « cauchero » quien lo hace solamente al caucho. La lexicografía cauchera ofrece otros préstamos lingüísticos, debidos sin dudas a la condición fronteriza de la industria, como « habilito », que deriva del portugués « aviamento ». Sobre las diferencias de las industrias caucheras en estos tres países ver Paredes Pando (2013). 
la industria extractiva; allí salda parte de la deuda y recibe un nuevo adelanto de mercaderías - teniendo el patrón, a la vez, derechos exclusivos sobre la compra de la goma y la venta de mercadería, con lo cual monopoliza tanto la producción como la reproducción. El patrón transporta luego la goma a una casa central, que administra numerosas barracas y comercializa el producto a través de puertos como Manaos o Belém do Pará llegando incluso hasta Europa; de hecho, muchas de las casas caucheras más importantes como Arana, Suárez o Braillard tienen sus filiales en Londres, y la industria amazónica abastece la demanda gomífera de Inglaterra, Estados Unidos, Alemania, Francia y Rusia entre otros países ${ }^{6}$. Basado en el circuito mercadería-goma-mercadería, pues, el sistema de « aviamento » o « habilito » constituye el auténtico motor de la industria: « La Amazonía es la tierra del crédito. No hay capital. El seringueiro debe al "patrón", el "patrón" debe a la "casa aviadora", la "casa aviadora" debe al extranjero, y así ${ }^{7}$. »

En este reino del crédito, el mayor problema práctico pasa por la logística y la disponibilidad de mano de obra, compuesta por poblaciones criollas, migrantes nacionales y extranjeros, y también por poblaciones autóctonas. Muchas veces esta fuerza de trabajo es captada de forma voluntaria; otras veces no, y el reclutamiento toma la forma inquietante del peonaje a deuda y el enganche forzoso. Una vez integrada al circuito del crédito por medio del « habilito », el endeudamiento de la mano de obra deviene permanente, llegando a caracterizarse en muchos casos como una auténtica forma de esclavitud ${ }^{8}$.

En este escenario general, la mayoría de las investigaciones sobre las poblaciones indígenas del período suele coincidir en tres puntos básicos. El primero es la oposición de « blancos »e « indios » como actores sociales homogéneos (pese a que, como veremos, abundan por un lado los datos sobre conflictos entre indígenas, o por el otro entre misioneros y caucheros). El segundo es la postulación de identidades que podríamos llamar genéricas (por fijación de 《 etnias » como « los cavineños », « los cayubabas », « los mojeños », etc.). El tercero es la canonización de una percepción fatalista del contacto, con muy pocos matices, que privilegia la descripción de fenómenos como las epidemias, las migraciones, el despoblamiento, los enganches forzosos o incluso la aniquilación de los indígenas, mientras deja de lado otros datos contemporáneos

6. Más allá de la participación de Perú o de Bolivia en la industria, la goma fue el gran motor de la exportación brasileña antes de la primera guerra mundial. De la región amazónica ocupada en 1880 por los tres países salieron 8.635 toneladas de goma, cuya enorme mayoría era de origen brasileño. Para 1910 la cifra era ya de 26.693 toneladas (Bethell 1991, vol. 7, p. 14).

7. Mario Guedes, cit. en Weinstein 1983, p. 23. Por más que la industria siga trabajando a escala local, el impulso macroeconómico del boom gomero se agota a partir de 1912, cuando cae el precio de la goma por la aparición en el mercado de plantaciones inglesas en Malasia, con cuyos precios no pueden competir las casas comerciales sudamericanas (véase Bethell 1991, vol. 10, p. 343).

8. Para una comparación con Perú y Brasil, ver Paredes Pando (2013). 
como las estrategias individuales y colectivas de esos mismos actores o bien sus criterios de interpretación de esas mismas coyunturas. Un examen desapasionado de la evidencia, creemos, permite matizar esos supuestos.

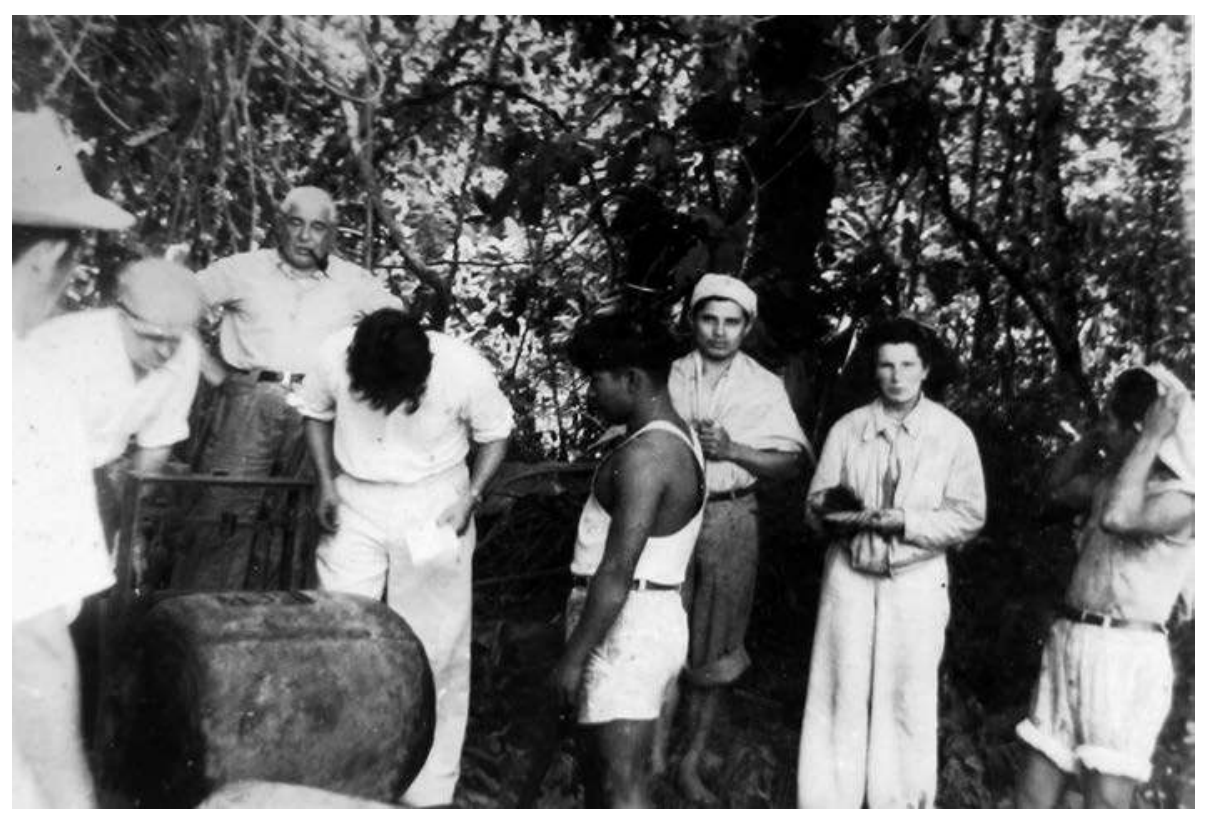

Fig. 2 - Emilia Hecker y personal de la empresa Hecker pesando bolachas de goma en una barraca (circa 1930).

Fuente: Colección privada de la familia Hecker, Riberalta.

\section{El discurso oficial sobre la cuestión indígena}

Como en otros países latinoamericanos, puede decirse que en Bolivia la legitimación de la puja colonizadora se cifra en un postulado básico: los indígenas deben someterse por las buenas o por las malas. «Por las buenas » implica que se integren al sistema de trabajo, asimilándose a la sociedad nacional. « Por las malas » que se transformen en un obstáculo que debe reprimirse, cuando no eliminarse:

Para librar de todo peligro la región comprendida entre el Acre y el Bajo Beni, que encontramos susceptible de un desarrollo industrial de primer orden, no hay otro medio que el de limpiarlo de salvajes, alejando a éstos sobre la margen izquierda del primero de dichos ríos [...]. Allí las causas constantes que actúan en la naturaleza como auxiliares de la civilización, los reducirán a la impotencia para el mal, si no los mueven a someterse al trabajo, para participar de los beneficios de la industria. (Pando 1897, p. 108) 
El argumento de José Manuel Pando es claro. El progreso no puede detenerse por las complicaciones que provocan los indígenas. Caucheros, colonos y misioneros son « héroes » que sobrellevan innumerables dificultades para anexar un territorio indómito. Si bien algunas voces denuncian excesos de los gomeros, que explican gran parte de la resistencia indígena, esto no puede detener la industrialización del Oriente (Quijarro 1893, p. 15-16). En 1895, por ejemplo, el teniente Pastor Baldivieso redacta un informe ministerial que reclama la « pacificación » del Alto Madidi y las zonas aledañas:

En todo este año [1896] han sucedido tres hechos desgraciados; el primero en la barraca « Filadelfia » del río Tahuamanu en la que el patrón, don Santos Adriazola, fue muerto por los bárbaros que perseguía [...]. El segundo hecho ha tenido lugar en las proximidades del « Manuripi » en un centro perteneciente a la empresa del « Carmen » en el Madre de Dios, un freguéz llamado Ruperto Gonzales que trabajaba con bárbaros conquistados por él fue asesinado durante la noche por sus propios peones que desaparecieron después de consumado el hecho. El tercero, en una pequeña barraca del río Orton en que un mayordomo que estaba a cargo de unos pocos bárbaros, ha muerto sin saber con seguridad si con alguna enfermedad o también asesinado; lo último es lo más probable a causa de la fuga de los trabajadores. (Baldivieso 1896, p. 60-61, resaltado nuestro)

Además del tono de las preocupaciones de la época, la cita muestra que se atribuyen hechos de violencia a los « bárbaros » sin demasiadas pruebas. Periódicos como La gaceta del Norte reportan un sinfín de crímenes en las barracas que muchas veces cometen los mismos gomeros por problemas laborales, mujeres, alcoholismo, etc. No obstante, en el imaginario oficial prevalece la idea de que la violencia es patrimonio casi exclusivo de los indígenas. Es por eso que hay que fijarlos, disciplinarlos, integrarlos a la órbita republicana. El problema es que los mismos agentes colonizadores comienzan a disputarse entre ellos el control de los indígenas como mano de obra, así como también la metodología para integrarlos a la realidad nacional. El franciscano Nicolás Armentia (1885, p. 6) observa que la reducción de las tribus salvajes debe ser una prioridad del gobierno no sólo desde el punto de vista religioso, sino también comercial: si el subsidio estatal a la labor misionera implica desembolsar una fuerte suma durante tres años, los resultados lo compensarán con creces. Los caucheros no civilizan a los indígenas sino que apenas los apaciguan mediante continuos regalos y donativos; en cambio, como argumenta Armentia con lógica weberiana, los indígenas de las misiones invariablemente se convierten en ciudadanos productivos ${ }^{9}$.

9. Para la antítesis laica de este argumento, ver Pando 1892, p. 4 (véase Córdoba 2012a). 


\section{Iguales pero diferentes: el indio civilizado}

Para comenzar a desmontar el imaginario canónico del indígena de la Amazonía boliviana es necesario establecer una primera gran diferencia entre los indígenas « civilizados », por un lado, y los « salvajes » $\mathrm{o}$ " bárbaros » por el otro. Como bien explica Guiteras Mombiola (2012), dentro del primer grupo se cuenta a los cayubabas, baures, movimas, canichanas, itonamas, mojeños y también a las « etnias » referidas en las fuentes como « ixiameños », « tumupaseños $»^{10}$, etc. Todos estos grupos se consideran « civilizados » porque son tempranamente reducidos al régimen misional jesuita, o luego al secular, y porque conocen entonces las reglas básicas de la civilidad. Un notorio divisor de aguas, asimismo, es que todos ellos son bautizados y poseen nombres y apellidos cristianos.

Hay bastante consenso sobre las virtudes de estos indios civilizados. Comerciantes, misioneros, políticos y militares refieren su gran destreza como remeros, imprescindible para atravesar las traicioneras cachuelas del Madera - hay que decir, a la vez, que muchas veces se habla de esta habilidad en general, sin referencia a ninguna etnicidad en particular. Ninguna partida gomera puede prescindir de la tripulación indígena:

Todas nuestras dificultades se evidenciaron en la experiencia de este viaje. No teníamos canoas, no teníamos indios, ambos absolutamente indispensables para navegar el Madera y sus rápidos y sus cataratas. (Craig 1907, p. 140) $)^{11}$

Pero a fines del siglo pasado, los propietarios de los centros gomeros recurrieron a los pueblos de Tumupasa, Isiamas, San José de Uchupiamonas, etc. en busca de gente, conocida ya en todo el Beni como sobria, sufrida y especialmente trabajadora; y al mismo tiempo que comenzó la grandeza y la fama mundial del Beni por su goma, comenzó también la decadencia de los pueblos nombrados, porque, desde aquella fecha, una gran parte de sus habitantes buscó trabajo en las barracas gomeras o en la navegación. (Mendizábal 1932, p. 145)

En términos generales, se constata una caracterización positiva - si bien genérica - de este « indígena civilizado », que muchas investigaciones recientes retoman para discutir las formas diversas bajo las cuales estas poblaciones logran integrarse al mercado y acceder a la ciudadanía plena (Van Valen 2003, 2013; Vallvé 2010; Guiteras Mombiola 2012).

10. Todo sugiere que se trata de los mismos grupos, o de mezclas entre ellos o acaso también con otros grupos, aunque categorizados en clave territorial más que étnica: así, se habla de los « indios de Ixiamas », donde habitaban por ejemplo los cayubabas, pero sabemos que allí también había otros grupos; en todo caso, vale destacar que se trata de criterios compatibles aunque a veces contradictorios (Brohan y Herrera 2008; Villar et al. 2009; Ferrié 2014).

11. Todas las traducciones son nuestras. 
Nuestro interés, aquí, es otro. Dilucidar quiénes son los « salvajes », los « bárbaros » que no se sujetan al régimen misional primero y que mantienen una actitud ambigua luego frente a la expansión cauchera: individuos y grupos que aparecen a veces como mozos fieles de algún empresario, otras comercializando sus productos con los siringueros, otras atacando las embarcaciones o a las barracas, e incluso asesinando a colonos y patrones caucheros. Las noticias suelen ser fragmentarias, cambiantes, contradictorias, y los mismos indígenas que supuestamente cometen crímenes atroces son reputados luego como trabajadores ejemplares.

\section{La barbarie domesticada: araonas y cavineños}

Puesto que nos interesa analizar a los « salvajes » durante el boom cauchero, comenzaremos describiendo a los indígenas que las fuentes describen trabajando en la goma. Aquí hay que hablar principalmente de araonas y cavineños, pertenecientes a la familia lingüística tacana, compuesta hoy también por los tacanas, maropas y ese' ejas ${ }^{12}$. En general los araonas son caracterizados como indígenas dóciles, aptos para la civilización, buenos trabajadores y excelentes rumbeadores por más que a veces también se les atribuyan acciones violentas. Son los primeros indígenas que aparecen en las barracas gomeras, como en la de Vaca Díez, llamada Puerto Rico, donde el cura Sanjinés (1895, p. 60) asegura que trabajan nada menos que 400 araonas:

Vive todavía un indio capitán, ya viejo, llamado Chumo [...] este deseaba bautizarse, y con la sencillez de un niño repetía: « Bárbaro, no bueno: yo cristiano ser. ¿Por qué bautizas a las criaturas y a mí no? » Apenas ver a estos infelices, hacinados entre diez, quince y más en una habitación sucia e inmunda, entregados a sus usos y costumbres de salvajismo, sin ninguna noción de moralidad, ni asomo de enseñanza cristiana; y sin embargo, se dice ¡hace más de diez años que ya están conquistados! (Sanjinés 1895, p. 60)

Más tarde vendrá la civilización, pero entretanto el salvaje y sobre todo el temible araona ya no teme ni persigue al hombre y, al contrario, seducido por la generosidad de Vaca Díez que le regala, cura y atiende, se convierte en servidor de las barracas. Caza, pesca, sirve para el transporte, se ocupa de remar, y entra por fin,

12. No hemos incluido aquí a los tacanas stricto sensu porque no suelen ser mencionados como « grupo » en las fuentes del siglo XIX. Obviamente se los confunde con los araonas o los cavineños por la superposición de criterios lingüísticos, étnicos, territoriales, etc. Sin embargo, algunos autores son concientes de la dificultad. Uno es el naturalista italiano Luigi Balzan (2008 [1885-1893], p. 174-175) y otro Marius del Castillo (1929, p. 254, 261), que registra un censo de la barraca Fortaleza en el río Beni: 111 peones son « oriundos del Beni » que hablan el tacana, mientras que otros 130 son efectivamente tacanas (en menor cantidad aparecen baures, maropas y lecos). Para mayores precisiones respecto del problema, véanse Brohan y Herrera 2008; Herrera 2011. 
en la comunidad de estos colonos que plantan allí la bandera de la civilización nacional. (Anónimo 1894, p. 8)

En la crónica de Edwin Heath también podemos apreciar el carácter predispuesto de los araonas, que participan de sus expediciones entre 1879 y 1883. Esta buena voluntad no impide que se les atribuya la práctica de la antropofagia, clásico cliché del salvajismo: « Casi todos los años vienen unos indios antropófagos Araunas que viven al lado del río Mano [...]. En el año 1879 uno quedó trabajando un mes, y en 1880, nueve se contrataron por dos meses » (Heath 1969 [1879-1881], p. 9-10). Los araonas no sólo proporcionan datos geográficos sino que acompañan en todo momento al norteamericano cuando sortea los escollos de las cachuelas y logra conectar por primera vez el río Beni con el Mamoré. Tal es la confianza mutua entre los araonas y el gomero Vaca Díez que éste los envía a navegar río abajo en busca de nuevos siringales (Heath 1896, p. 21-22). Por su parte, los araonas dicen: « Al tata doctor [Vaca Díez] lo queremos porque nos da herramientas para trabajar nuestras chacras; nos da de comer a tantos que vinimos cada año y nunca nos ha hecho mal. Deseamos que sea nuestro jefe, que nos mande y nos defienda de los pacaguaras que son nuestros enemigos » (cit. en Chávez Saucedo 2009 [1926], p. 134).

Encontramos nuevamente a los araonas en la expedición del coronel brasileño Antonio Labre, que parte de la barraca Maravillas, propiedad de Víctor Mercier y Timoteo Mariaca, y explora la cuenca del Madera con una comitiva que incluye 15 araonas « semi-civilizados ». Los expedicionarios encuentran a varios araonas que viven en buenas relaciones con los comerciantes (Quijarro 1893, p. 11; Royal geographical society 1889, p. 496-499). En el relato de viaje que envían a Vaca Díez, en 1887, y que La gaceta del Norte publica en fascículos, observan:

Llegamos a una chocita provisionalmente construida, donde habitaban cinco salvajes araonas con sus esposas [...]. Nos recibieron con mucho cariño, brindándonos los pocos alimentos con que contaban [...]. Atraídos por la buena hospitalidad que recibimos, resolvimos pasar la noche con ellos. (La gaceta del Norte, 23 de octubre de 1887)

El propio coronel Pando, una de las voces más duras sobre la cuestión indígena, reconoce asimismo que los araonas son « los únicos que se prestan a la civilización », refiriendo que trabajan para un tal Cárdenas en la barraca Camacho (Pando 1897, p. 36) ${ }^{13}$. Otro testimonio importante es el de Manuel Ballivián, para quien el principal problema del siringuero - prócer del trabajo y del progreso -

13. Paradójicamente, y como para no perder de vista el horizonte de ambigüedad que caracteriza a las relaciones interétnicas, en ese mismo establecimiento un araona asesina a su mujer unos años más tarde, y vuelve a surgir la grotesca acusación de canibalismo: «Un indígena antropófago. Uno de los centros del establecimiento Camacho ha sido teatro del horroroso crimen que vamos a relatar, cometido por un indio de la tribu Araona en la persona de su consorte y cuyos nombres ignoramos. Es el hecho que el marido, cegado por 


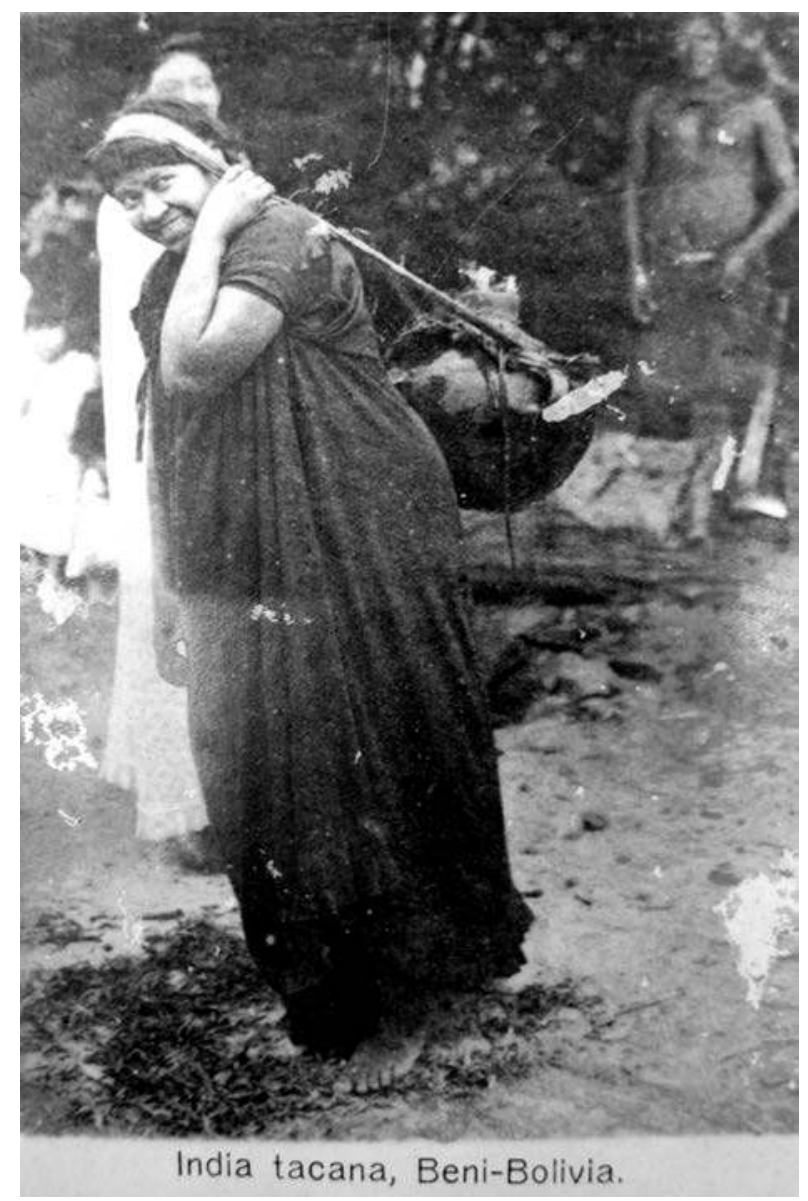

Fig. 3 - Postal « India tacana, Beni ».

Fuente: Colección privada de la familia Hecker, Riberalta.

los celos, aprovechando que su mujer se hallaba en completa beodez, dio principio a su desenfrenada antropofagia, comiéndose las partes genitales, un brazo, el pómulo derecho y la nariz. Es de advertir que este monstruoso salvaje, antes de comenzar a su tarea, ya se había devorado medio chancho crudo » (La gaceta del Norte, 15 de septiembre 1904). Si esta denuncia no parece demasiado seria tampoco parecen serlo las acusaciones del cura Sanjinés, que atribuye a « los araonas del capitán Nico » un asesinato en la barraca Humaitá, en venganza por los excesos gomeros. Sabemos que el propio Pando (1897, p. 106) atribuye este mismo hecho a los indios caripunas, y que en la tribu del susodicho Nico (caripuna) hay mezclados pacaguaras y caripunas, pero no araonas. De igual modo, el tipógrafo Juan Coimbra es el único en afirmar - erróneamente - que los araonas asesinan al cauchero Gregorio Suárez (2010 [1946], p. 140). 
es la captación de mano de obra. Si bien admite las correrías que los gomeros emprenden para proveerse de trabajadores entre los indígenas, describe a la vez las tentativas para entablar relaciones comerciales o amistosas con ellos. Su descripción de los araonas reitera el tema de su adaptabilidad a la industria siempre y cuando puedan mantener sus chacras y sus familias, comercializando la goma en su territorio y bajo sus propias condiciones (Ballivián y Pinilla 1912, p. 67-70, 80).

La caracterización de las mujeres araonas no es menos elogiosa. La alusión a su belleza se revela tan importante como su docilidad:

El tipo araona es agraciado, de esbeltas formas y cutis bastante limpio. Las doncellas, sobre todo, son muy apetitosas. Vestidas a la europea, en nada desmerecen de las cruceñas, en concepto de algunos aficionados del Beni. En las barracas son las odaliscas del barraquero; en Riberalta he visto más de una mujer araona casada canónicamente y convertida en excelente ama de su casa. Un comerciante alemán había llevado una de estas indias a Europa, la hizo educar en un colegio, casó después con ella y puedo asegurar que por su educación y cultura es toda una señora, de las más señoras que conocí en el Beni. (Bayo 1911, p. 317, resaltado nuestro)

La anécdota de una joven araona casada apropiadamente con un alemán sólo tiene correlato en un matrimonio entre un europeo y una mujer cavineña, y no se repite en ninguno de los demás grupos « salvajes »-imposible encontrar un caso similar entre caripunas o pacaguaras. En efecto, la cuestión de las esposas indígenas nos sirve de transición a la representación contemporánea de los cavineños. Quien tiene una esposa cavineña es Eugène Robuchon, explorador francés tristemente conocido por su desaparición en la selva peruana en 1906, en circunstancias poco claras, trabajando para el barón cauchero del Putumayo, Julio César Arana. Desde 1893 a 1902 Robuchon recorre el Madre de Dios y recoge a una indígena cavineña a quien lleva a Europa, causando sensación en varios periódicos de la época. La indígena se bautiza, toma la primera comunión y adopta el nombre de María Margarita Hortensia Guamiri, para luego contraer matrimonio con el francés. En 1903, la nota periodística sobre un encuentro en la Sociedad de Geografía de Nantes dedica varias líneas a la descripción de esta mujer:

Hay que escuchar a nuestro explorador mismo contar cómo cuando descendía el curso de uno de los afluentes del río Amazonas, percibió una joven de la antigua raza americana que parecía buscar refugio; cómo le dirigió la palabra en la lengua de los salvajes, cómo le ofreció protegerla y ayudarla a encontrar a su familia y su tribu [...]. Ella se mostró tan inteligente y dedicada que M. Robuchon no dudó en hacerla su compañera para el resto de su vida y se casó con ella [...]. Ella nos ha parecido grande y fuerte; no está desprovista de gracia en su traje todo europeo, y si bien sus rasgos difieren un poco de la raza caucásica, su figura no carece de encanto y respira bondad. La tribu Cahivas [Cavinas], a la cual pertenece, es conocida por la dulzura de sus costumbres y carácter. (cit. en Echeverri 2010, p. 32-33) 
Estos indígenas provienen de la antigua misión de Cavinas y por ende se los conoce como « cavineños ». Tal vez su frecuente aparición en las fuentes se deba a que se encuentran en el epicentro de la fiebre cauchera y que muchas veces trabajan con los propios siringueros, o bien con los curas que administran la extracción de la goma en la misión (Nordenskiöld 2001 [1924], p. 345). De hecho son ellos quienes ayudan a Pablo Salinas, un comerciante de Reyes, a explorar la selva circundante a la reducción y a descubrir su potencial gomero (Sanabria Fernández 2009 [1958], p. 32-33). El cura Sanjinés describe el sistema de habilitación de los cavineños: « Los cavineños se ocupaban de picar la siringa de su cuenta, para venderla a [Miguel] Apuri, de quien recibían habilitación [...]. Misión de Cavinas. El pueblo hoy cuenta con 148 almas [...]. Me informan que están afuera, en las barracas, unas 12 familias, las que podrán ser recogidas, pagando sus cuentas » (Sanjinés 1895, p. 18-19). Según las informaciones de Armentia y Balzan, cuando los cavineños se quedan sin misioneros, entre 1885 y 1897, se dedican a trabajar como siringueros (Brohan y Herrera 2008, p. 268-269).

Una fuente importante para el período son los censos de 1910 de la barraca San Francisco, de la Casa Suárez, que reportan un total de 146 trabajadores, de los cuales 38 provienen de Santa Cruz de la Sierra mientras que 70 responden a la denominación « cavinas/cabinas/caviñas »; o sea que casi la mitad del personal es cavineño (ACS, « Censos de los ríos Manuripi, Madre de Dios, Orton y Tahuamanu de 1910 »). En cambio, en el censo de 1910 de Cachuela Esperanza las procedencias de los más de 200 empleados se dividen entre « francés », 《 alemán », « chileno », « suizo », « Santa Cruz », « Cochabamba », o bien entre distintos ríos, y las filiaciones indígenas más frecuentes son « Cayubaba», « Baure », « Chiquito », « Movima » o « Canichana ». Podemos pensar, pues, que mientras que en la central del imperio gomero trabajan los indios " civilizados », en los puestos más alejados lo hacen los indígenas « menos civilizados », aunque dóciles o al menos adaptables, como los araonas o los cavineños ${ }^{14}$. Siguiendo esta lógica concéntrica, encontraremos luego a los « bárbaros » pacaguaras, caripunas o chacobos pululando en la periferia más satelital de la industria gomera.

Otros caucheros de menor escala también refieren las buenas relaciones que establecen con los cavineños:

14. No siempre los documentos indican la filiación étnica del trabajador en lugar de su apellido, y en esos casos se trata mayormente de movimas, cayubabas o canichanas. Otras veces aparece consignado el lugar de nacimiento (por ej. río Orton) y se indica « Araona » como apellido. No obstante, hay que recordar que estos censos no contemplan la totalidad de la población indígena que efectivamente trabajó para la firma, pues no era raro que se perdieran los nombres de los picadores indígenas, último eslabón de la cadena productiva (Frederic Vallvé, comunicación personal). 
En el mes de junio siguiente [1884] me entregué de lleno a la explotación de la goma, sin temer a los bárbaros, como que en efecto, habiendo avanzado unas dos leguas hacia el interior del bosque, ya encontré una tribu de 28 almas cuyo capitán llamado Ecuari entrando en relaciones conmigo, me entregó un hijo suyo de corta edad [...]. Continuando mi marcha más al interior con ayuda del capitán Ecuari, encontré también otra tribu de 15 matrimonios con su capitán Ino. Al mes siguiente expedicioné sobre el Tahuamanu y en la margen derecha encontré al capitán Capa, en la tribu Buda, con una población de ocho matrimonios. La primera población que descubrí pertenece a los cavinas y las dos últimas a los Araonas [...]. Yo me quedé haciendo picar gomeros con mis mozos propios y con los bárbaros que ya concurrían voluntariamente de las tres tribus descubiertas por mí. (Mariaca 1987 [1887], p. 11)

Dos años más tarde, cuando una inundación arruina sus provisiones, Mariaca envía a cuatro araonas y dos mujeres cavineñas en busca de ayuda al Abuná. Lo interesante es que la solución al dilema logístico no surge del seno de los « salvajes dóciles », puesto que la comitiva regresa con alimentos que obtiene de los pacaguaras (Mariaca 1987 [1887], p. 12-14) ${ }^{15}$. Esta noticia, así, nos sirve de bisagra para pasar a la otra gran categoría de « bárbaros », menos adaptables y definitivamente más complicados.

\section{La barbarie indócil: pacaguaras, caripunas y chacobos}

Los pacaguaras, caripunas y chacobos pertenecen a la familia lingüística pano (Erikson 1993, Villar et al. 2009). En el período cauchero, los pacaguaras aparecen mencionados lateralmente en algunas barracas, como cuando Sanjinés habla de ciertas familias que pican goma para un señor Pardo en el arroyo Ivon (1895, p. 60-61). Armentia refiere que el padre Ciuret le presenta a una pacaguara del Madre de Dios que dice tener parientes en Mamorébey, lo cual coincide con lo que cuentan los mozos de Vaca Díez, que se enfrentan con ellos en ese mismo lugar (Armentia 1976 [1882], p. 32-33, Heath 1896, p. 16). Clements Markham (1883, p. 324) observa campamentos gomeros asistidos por pacaguaras, que les proveen bananas, caña de azúcar y mandioca. Lo mismo reporta el ingeniero Edward Matthews (1875, p. 58), quien se encuentra con un hombre y niño pacaguaras en el río Tres Hermanos: ambos se comportan bien, visten ropas occidentales e intercambian con el viajero plátanos y maíz por machetes, hachas y anzuelos. En su expedición por el río Beni, Edwin Heath $(1896$, p. 16) también se topa con una familia de pacaguaras viviendo con el gomero Fidel Endara, ayudándolo con el caucho, con la navegación y con las imprescindibles plantaciones de mandioca, arroz, caña, etc. Más que involucrados de forma directa, como los araonas o los cavineños, los pacaguaras

15. Si bien la historiografía de las relaciones interétnicas entre los panos y tacanas de la Amazonía boliviana está apenas en su fase inicial, parece indudable que existió un entramado de intercambios que iba mucho más allá de las fronteras lingüísticas (Brohan y Herrera 2008; Villar et al. 2009; Coffaci de Lima y Córdoba 2011). 
aparecen pues comerciando con los caucheros, participando indirectamente de la reproducción del sistema extractivo.

Sin embargo, la mayoría de los testimonios son menos positivos. En primer lugar, todos recuerdan la matanza de la barraca Buen Retiro:

En junio de 1893 la barraca Buen Retiro del bajo Beni fue asaltada por una horda de salvajes pacaguaras, en circunstancias en que la población masculina se hallaba en las labores de pica. Los asaltantes dieron muerte a unas cuantas mujeres, y entre ellas a la del capataz Manuel Jesús Parada y a varios niños, y después de pillar cuanto objeto metálico estuvo a su alcance, emprendieron la fuga hasta el cobijo de la selva. Al regresar los hombres de la faena y ver las víctimas del malón no vacilaron en emprender la expedición de castigo hasta el norte, siguiendo las huellas de los asaltantes, y al fin hubieron de alcanzarles en las cercanías de un arroyo que fue conocido desde entonces con el nombre de Pacaguara. (Sanabria Fernández 2009 [1958], p. 76) ${ }^{16}$

El comandante Herbert Edwards, que recorre la frontera entre Brasil y Bolivia desde 1911 a 1913, propone una lectura diferente de los hechos. Las orillas del río Abuná y del Río Negro son la tierra de cacería de los pacaguaras, que la defienden celosamente del avance de los gomeros (Edwards 1915, p. 394-395). El militar nos ofrece una detallada descripción de estos indígenas, y sostiene que la violencia no es más que una reacción ante los atropellos gomeros:

Durante nuestro retorno a Fortaleza, nos encontramos con una partida de pioneros que tras una ocupación de apenas pocos meses acababan de ser echados del distrito del Río Negro por un raid organizado de los pachaquara, perdiendo incluso a varios hombres que murieron [...]. Viviendo una vida libre y sin restricciones en su antiguo dominio, es natural que a los indios les desagrade la intrusión de gente cuyo objetivo es explotar los árboles de goma para su propia ganancia, y cuya incursión en los bosques remotos aleja a las presas de caza y arruina la caza tribal. (Edwards 1915, p. 390-391, cf. del Castillo 1929, p. 110)

Igualmente explícito es el relato del coronel Percy Fawcett (1954, p. 135), que antes de emprender su viaje es precavido respecto de la amenaza de las flechas envenenadas de los pacaguaras. Lo cierto es que el célebre explorador se topa con una experiencia bien distinta. En 1907, en Cachuela Esperanza, mientras visita la central de la casa Suárez, dieciséis pacaguaras aparecen de repente navegando en canoa por el río sin notar el alboroto que causa su presencia: cunde la alarma, los peones gritan y todos lanzan órdenes contradictorias mientras disparan histéricamente contra los indígenas.

Los salvajes ni se inmutaron. El río, en ese punto, tiene seiscientas yardas de ancho, o sea, casi el límite del alcance de un Winchester cuarenta y cuatro. Con serena

16. Véase Limpias Saucedo 2005 [1942], p. 240-241. Según Torres López (1930, p. 194 198 ), en cambio, los protagonistas de la matanza son los caripunas. 
dignidad, los indígenas pasaron de largo, hasta perderse en algún pequeño afluente. Hubo rostros malhumorados después de la orden de « ; cese el fuego! », cuando se hizo un balance del gasto de municiones de precio exorbitante. (Fawcett 1954, p. 147)

El viajero alemán Richard Wegner afirma que en esa época los pacaguaras suelen aparecer por el Orton y el Abuná atacando los campamentos siringueros. Los caucheros emprenden por su parte expediciones punitivas matando a los hombres y llevándose a las mujeres y a los niños. Wegner refiere, por ejemplo, la anécdota de un timonel que rapta una mujer pacaguara del Madidi y la toma por esposa, pero luego la deja porque ésta defeca en la hamaca que comparten por las noches (Wegner 1936, p. 246-247).

Así se va construyendo el estereotipo sobre los pacaguaras: díscolos, sucios, peligrosos, imprevisibles. Su aspecto, su lengua, sus costumbres, todo los diferencia de los salvajes más dóciles como los araonas o los cavineños ${ }^{17}$. El reporte de la expedición de Labre y Mercier subraya en todo momento que los acuerdos con ellos son siempre frágiles, y que hay que entregarles constantemente mercaderías para apaciguarlos.

De aquí se adelantó Mercier llevándose a los guías y todos los obsequios destinados para los salvajes [...]. Era que estábamos sobre la primera población de Pacaguaras, donde esperaba Mercier ser recibido como un genio bienhechor y poder conseguir así algunos muchachos autoritativamente pero a cambio de los objetos llevados de esta Colonia, para conseguir el pasaje y nada más, a la comisión exploradora. (La gaceta del Norte, 23 de octubre de 1887)

En estas circunstancias, no sorprende tampoco que se les endilguen los crímenes más grotescos:

A fines del mes de abril, la tribu salvaje de los pacaguaras asaltó la barraca de los señores Suárez y Durán, entre el Río Negro y el Abuná, matando al capataz Benjamín Pérez y a la sirviente Petrona Paniagua. El primero fue descuartizado, llevándose los salvajes, tal vez como bocato di cardinali, ambos brazos. A la segunda intentaron llevársela consigo; pero los gritos de socorro a sus compañeros, próximos a la barraca, obligaron a los salvajes a ultimarla a hachazos, con la misma herramienta que acababan de robarse en el saqueo de la casa. Esta tribu feroz y probablemente antropófaga es la misma que, hace años, asaltó también la barraca del señor Santos Mercado, sobre el río Beni, y la que años más tarde le dio muerte en su establecimiento industrial del Abuná. (La gaceta del Norte, 15 de junio de 1906)

17. Lo que más llama la atención es la ornamentación facial, como por ejemplo el rësëti, adorno nasal colocado en los rituales de iniciación, hecho generalmente de caña y adornado en sus extremidades con plumas de aves (Córdoba 2008): « El Pacaguara se diferencia a primera vista por la manera de desfigurarse la cara [...]. Las orejas se traspasan con largos dientes de jabalí, de un peso considerable. El pene está atado al abdomen con un cordel que se amarra en un cordón de cintura » (La gaceta del Norte, 9 de noviembre de 1887). 
No obstante, si en las percepciones caucheras los pacaguaras se presentan como bárbaros irrecuperables, hay que decir que sus parientes caripunas son retratados como iguales o aun peores. Labre y Mercier relatan que encuentran una gran tribu de caripunas « quienes al divisarnos dieron muestras de marcada alegría, salieron a nuestro encuentro y nos hicieron suponer que estas espontáneas manifestaciones eran hijas de la sinceridad », pero se equivocan, pues los indígenas tratan de atacarlos a traición durante la noche (Mercier 1981 [1894], p. 11). Pando no admite medias tintas: « El Caripuna es pérfido y no hay medio de reducirlo al trabajo; para asegurar este territorio y fomentar la industria gomera, la primera medida que se debe tomar, es la de alejarlos o destruirlos por medio de frecuentes batidas » (1897, p. 105-106). El militar asegura que los caripunas del Abuná frecuentan las cachuelas del Madera para prestar auxilio a los viajeros si los superan en número, pero también para atacarlos sin misericordia si son menos que ellos (Pando 1897, p. 106). No se trata del único testimonio:

Los caripunas son los que atacan las tripulaciones que hacen el transporte de la carga del comercio de San Antonio al Mamoré y de éste al río Beni. Estos mismos son los que atacan los establecimientos gomeros del Bajo Beni y Orton, hasta la altura de Puerto Rico. Son temibles en sus asaltos y precipitados en la fuga [...] cuando son tomados de sorpresa y conducidos como prisioneros, por mejor trato que se les dé, prefieren morir antes que aceptar alimento del enemigo. ¿Serán antropófagos? No cabe la menor duda; y si lo son, no es precisamente por necesidad de carne, sino por la sed de sangre de su carácter belicoso. (Ballivián y Pinilla 1912, p. 75-76)

Sin embargo, lo curioso es que en las fuentes brasileñas los caripunas son percibidos de forma muy distinta. Una hipótesis que podemos arriesgar es que estos indígenas habitan la frontera del Acre, problemática entre Bolivia y Brasil, y que muchas opiniones sobre ellos varían en función de la lógica nacionalista. Los caripunas (brasileños) compiten con los chacobos/pacaguaras (bolivianos) por la autoctonía regional: Palacios explora los ríos para el gobierno boliviano y encuentra chacobos por todas partes; los Keller Leuzinger lo hacen para el gobierno brasileño y no encuentran otra cosa que caripunas (Villar et al. 2009, p. 98). Henry Pearson, que describe las relaciones entre los indígenas y las empresas brasileñas que construían el ferrocarril Madera-Mamoré, evoca con nostalgia la abundancia de tortugas y pescado en los campamentos ferroviarios, provistos por los caripunas (1911, p. 128). Neville Craig incluso afirma haber visto caripunas trabajando en las barracas: «Arauz tenía una treintena de personas en Tres Hermanos, fundamentalmente recolectores de goma bolivianos y sirvientes domésticos con cuatro indios caripunas [...]. Vivían por sí mismos en una choza vieja, pescaban un poco y eran aun más indolentes que los bolivianos » (1907, p. 256-257). No menos positiva es la opinión de los Keller Leuzinger (1875, p. 57-58): 


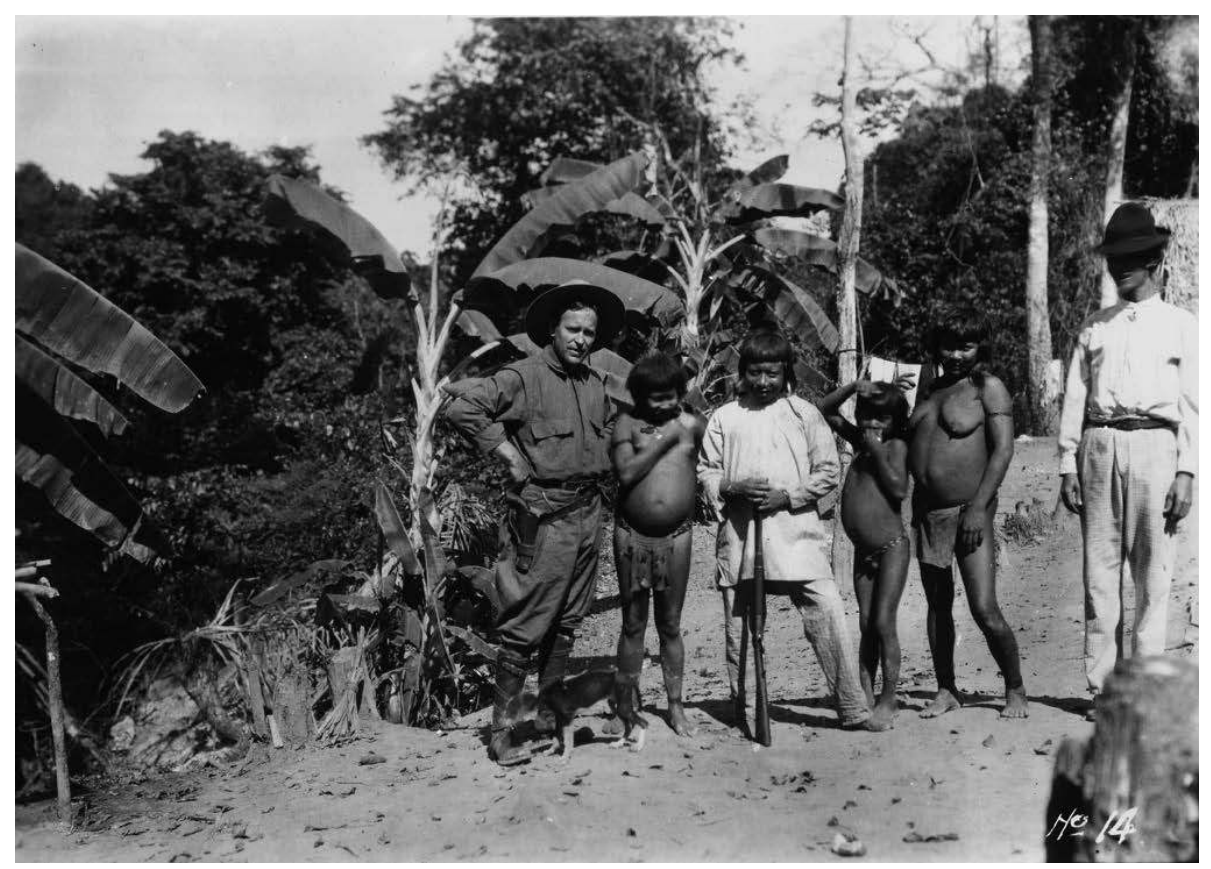

Fig. 4 - «Indios Caripunas en la construcción del

FFCC Madera-Mamoré (circa 1909) ».

Fuente: Colección Dana Merrill, Catálogo del Museo Paulista de la USP-BNDES.

[Caripunas] Los tripulantes, hombres y mujeres, en número de 10 a 12 , de los cuales los primeros iban desnudos, nos convidaron para ir a la ranchería. Aceptamos brindándoles cuchillos, tijeras, anzuelos, etc. En cambio nos dieron algunas raíces de yuca y maíz. (Keller Leuzinger y Keller Leuzinger 1870, p. 11)

Nos enteramos de que unos meses después la misma tribu había atacado el bote de un mercader boliviano matando al propietario y a cinco de sus vendedores, mientras que su esposa, gravemente herida, había logrado escapar con el resto de los mismos en una de las canoas [...]. Sin dudas, lo que sucedió fue que los bolivianos estaban atareados conduciendo a sus botes a través de las rocas, y la dispersión de la tripulación impidió cualquier resistencia seria. No podemos asegurar en modo alguno si una provocación del lado boliviano había precedido al atentado. Por detrás del « patrón » los vendedores pudieron haber provocado la cólera de los indios, especialmente por el comportamiento brutal para con las indias. (Keller Leuzinger 1875, p. 149-150)

Con mayor o menos claridad, pues, los testimonios brasileños parecen sugerir que la violencia interétnica es un pecado exclusivamente boliviano. En líneas generales, de hecho, la literatura boliviana ciertamente acumula referencias 
negativas sobre los caripunas, y algunos autores hasta les imputan la matanza de Buen Retiro - atribuida, como hemos visto, a los pacaguaras. Baldivieso informa que por todas partes hay caripunas armados con rifles que asaltan las barracas en el Acre (Baldivieso 1896, p. 61). Para el coronel Quevedo (1875, p. 177), si bien estos indígenas son « tratables », no dudan en cometer actos de violencia. Otro testimonio es el del escritor español Ciro Bayo: « Los verdaderamente peligrosos son los bárbaros que habitan la banda brasileña, entre la boca del Itenes y la cachuela Bananera, los guaras, tribu caripuna, tan bravos y arrogantes, que entran en batalla campal con los viajeros, de los que ordinariamente se apodera el pánico » (Bayo 1911, p. 339). Hay que recordar, en este punto, que los caripunas son los principales imputados por el asesinato del cauchero Gregorio Suárez, en 1873, vengado cruelmente por su hermano Nicolás Suárez, el patriarca gomero que justamente financia de forma privada buena parte de las tropas bolivianas que enfrentan a Brasil durante el conflicto del Acre. Ciro Torres López (1930, p. 194-198) afirma que es un secreto a voces que Nicolás Suárez venga a su hermano dejando latas de alcohol envenenado a orillas del río, que acaban con gran parte de la tribu ${ }^{18}$. Franz Ritz, un suizo que trabaja para la empresa Braillard, narra los incidentes con un nivel de detalle escabroso:

Por otro lado [los caripunas] habían matado a un hermano de Suárez. Él había hecho un viaje de Cachuela Esperanza hacia San Antonio. Un día del viaje, él [Gregorio] recibió la visita de un grupo de garipunas y en esta oportunidad quiso convencerse de si los salvajes eran tan buenos con el arco como se decía. Fueron con flechas y eligieron un blanco. Para mostrarle a los indios que él también se sabía defender muy bien, tiró con su Winchester al mismo blanco con el mismo éxito con que los indios lo hacían con sus flechas. Uno de los indios pareció interesarse en su arma y le hizo saber a Suárez que él también quería intentar tirar. Suárez le explicó el mecanismo y le entregó el arma. Súbitamente el salvaje se volvió con el arma contra Suárez y le disparó. El tiro lo mató y los restantes indios se arrojaron sobre Suárez para robarle la mercadería, aquella que se podían llevar [...]. El indignado Suárez [Nicolás] mandó entonces por ese tiempo una expedición de castigo, que viajó con botes de caucho río hacia abajo en el Madera. Como se esperaba, apareció una tarde un grupo de garipunas y se acercaron al bote. De la manera usual fueron obsequiados con té dulce y luego se sirvieron los licores. Suárez había envenenado una parte de los licores con estricnina y los salvajes se emborracharon. Poco tiempo después, naturalmente todo el grupo se murió. Suárez había vengado a su hermano. (Ritz 1934, p. 37)

El polo opuesto de este salvajismo irreductible es personificado por los chacobos, descriptos generalmente como indígenas « dóciles » o « mansos » que incluso visitan en grupo los pueblos como Exaltación:

18. Si bien no menciona directamente a la dinastía Suárez, el etnólogo italiano Andrea Landi comenta el episodio refiriendo que « un boliviano » envenenó alcohol con arsénico para dárselo a los caripunas en venganza por la muerte de un hermano (Landi cit. por Giglioli 1906, p. 222). 
Los indios que ocupan la banda boliviana del Mamoré [...] son los chacobos y sinabos, tribus mansas de la nación pacaguara, que a veces visitan Exaltación de Mojos y a menudo salen al encuentro de los navegantes, que los llaman « indios gritones » por los japapeos o ademanes y gritos violentos con que llaman la atención [...]. Van completamente desnudos, aunque disimulan lo que la decencia manda tapar, con un artificio que despierta hilaridad de los viajeros del Mamoré; los cuales, sin distinción, regalan a esta pobre gente con tabaco, yucas y plátanos, amén de algún trago de aguardiente que contribuye a que la despedida sea más ruidosa que la bienvenida (Bayo 1911, p. 338).

Luigi Balzan también los caracteriza como seres amistosos, calificados como « indios gritones » por su costumbre de salir al encuentro de los navegantes gritando y haciendo ademanes para captar su atención (Balzan 2008 [1885-1893], p. 331). Si bien suelen ser ponderados como amigables, a veces los chacobos también provocan problemas, sobre todo relacionados con el ganado salvaje que ronda los campos situados entre Beni y el Mamoré, que consideran propio (Bresson 1886, p. 494; Arauz 1868, p. 201-202; Matthews 1875, p. 38). Hay noticias incluso de fugitivos movimas y cayubabas que huyen de las barracas para instalarse entre ellos:

Salían antes con frecuencia al río Beni, a buscar plumas para flechas; según han declarado algunos Cayuvabas, que después de haber residido algún tiempo entre los Chacobos, se salieron y han entrado a los trabajos de gomas en el río Beni. (Armentia 1976 [1882], p. 137)

En 1909, Erland Nordenskiöld visita a los chacobos. Confiesa que debe pagar « un precio escandaloso » a un tal Vargas para que lo guíe hasta ellos. Vargas posee una plantación de caucho en el lago Rogoaguado, y hay con él « algunas mujeres chácobo y sus hijos ». Junto a Vargas, a sus hijos y a un muchacho chacobo, el sueco emprende el viaje, rodea el lago y finalmente llega al río Caimanes, donde encuentra una aldea chacobo y comienza a atisbar la verdadera naturaleza de la relación entre Vargas y los chacobos:

Después de dos días llegamos a un bosque en el que hace cuatro años Vargas visitó a los chácobo. Nos dice que llegó a ser un buen amigo de ellos y que les había ayudado en su lucha contra otra tribu, posiblemente los sirionó. En estas luchas murieron dos chácobo, y sus mujeres e hijos siguieron a Vargas hasta su casa, a donde viven ahora. Uno de éstos es el muchacho que nos acompaña. Pero parece que no se fueron con él tan libremente, como se desprende de lo que más tarde advertí. (Nordenskiöld 2003 [1922], p. 89)

Luego de unos días llegan a otra aldea cercana al río Yata, donde logran ser bien acogidos; sin embargo, cuando regresan, advierten que los chacobos han atacado la cabaña del cauchero en clara señal de enemistad, pues, según parece, las mujeres y los niños indígenas no se habían ido con Vargas por voluntad propia (Nordenskiöld 2003 [1922], p. 121). 


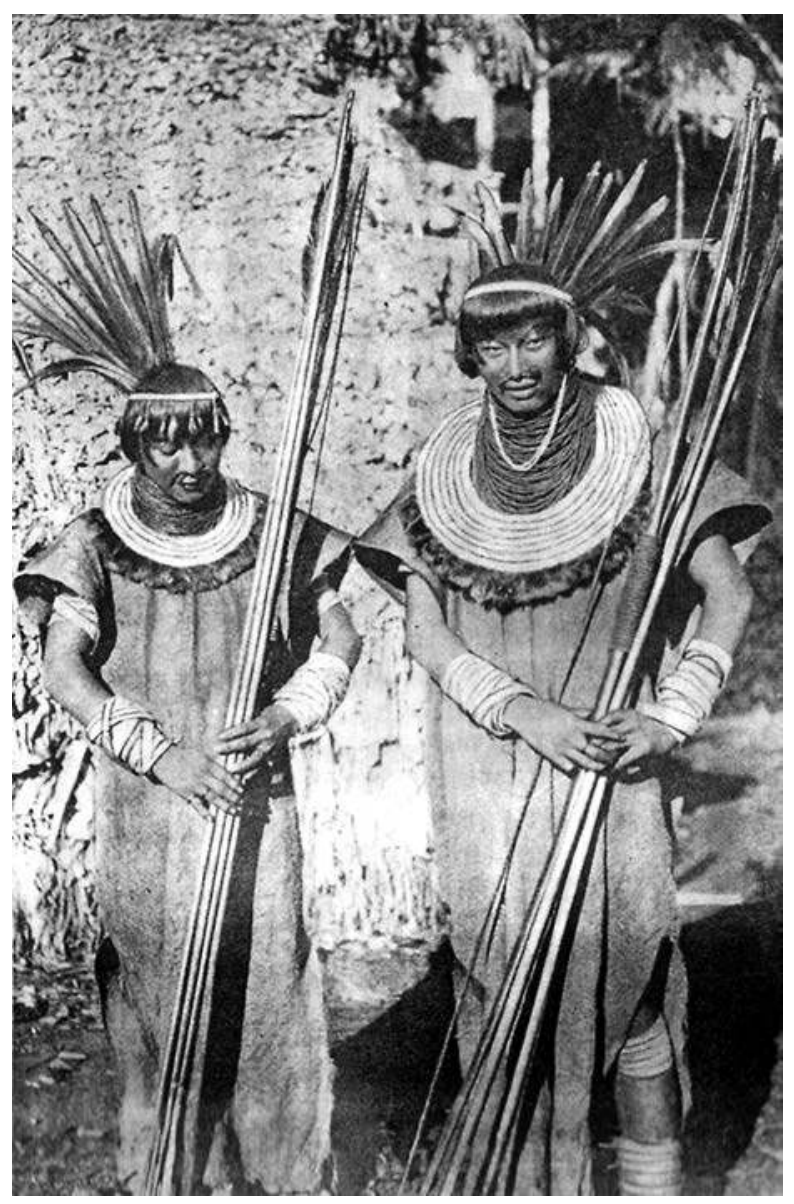

Fig. 5 - « Jóvenes chácobos. En el pecho, entre otros adornos, llevan collares de dientes de mono ». Fuente: Nordenskiöld 2003 [1922].

Mansos, amigables, gritones, dóciles, apacibles: son algunos de los epítetos más frecuentes para describir a los chacobos. A diferencia de sus parientes pacaguaras y caripunas, las fuentes no suelen caracterizarlos en forma negativa. Son considerados salvajes por su desnudez, o por sus adornos corporales, pero a la vez todos los testimonios coinciden en recalcar su trato amable. Si bien no trabajan la goma durante el boom cauchero - pues aprenden a hacerlo recién en la década de 1960, por iniciativa de los misioneros del Instituto Lingüístico de Verano (Córdoba 2012b) ${ }^{19}$ - los chacobos merodean las barracas:

19. Debido al recorte diacrónico escogido para este trabajo (1870-1910), no disponemos de fuentes orales sobre la otra cara de la moneda, con el testimonio directo de la visión indígena 
El día de mi salida llegó una tropa de salvajes a la barraca. Eran chacobos [...]. Los chacobos mantenían una relación amistosa con mi anfitrión. Se mezclaban con los obreros, a los cuales conocían aparentemente de visitas anteriores. El motivo de su visita era mendigar azúcar y fósforos. También les gusta fumar cigarrillos, cosa que sólo aprendieron en la barraca. En casa no fuman, tampoco tienen tabaco. (Ritz 1934, p. 138-139)

Carl Blattmann trabaja como contador y fotógrafo aficionado en Cachuela Esperanza, lo que le permite retratar la vida en la central así como en las barracas. En su colección de imágenes hay dos fotografías de chacobos retratados a pocos meses de su llegada a Bolivia, en 1906, bajo el título de « Chacobos » y « Bárbaros bailando ». Las fotografías son tomadas en asentamientos relativamente cercanos a Cachuela Esperanza, en un evidente clima de buena voluntad (Centeno y Fernández 1998, p. 23-24). Recordemos, por otra parte, que se trata del mismo lugar y casi del mismo período en el cual la aparición de una canoa con pacaguaras provoca una alarma general y varias descargas de fusilería: sin embargo, los chacobos son bien recibidos en Cachuela cuando buscan herramientas, azúcar, sal, etc.

Nuestro último testigo también es suizo y trabaja para Nicolás Suárez. Ernst Leutenegger se casa con la hija mayor del patriarca gomero, Esperanza, y luego dirige la sucursal de la empresa Suárez \& Filhos en Belem do Pará. Al separarse de Esperanza se muda a Londres, donde sigue trabajando para la compañía hasta su muerte en 1942. Cuando escribe sus andanzas bolivianas, Leutenegger afirma que no recuerda chacobos trabajando en las barracas, pero sí otros indígenas. Traba amistad con varios chacobos, e incluso salva la vida del hijo enfermo de un cacique. Y a los chacobos, justamente, dedica el final de su libro:

Bajó el precio de la goma... La Madera-Mamoré fue inaugurada... Cachuela: progreso... Clubes... tenis... cine... teatro... hospital... Únicamente mis antiguos vecinos, los indios Chacobo de los ríos Benicito y Geneshuaya, no se habían dejado

\footnotetext{
- o mejor, de las percepciones indígenas - acerca del boom cauchero. La construcción del imaginario del nativo en estas condiciones, que incluyen la innegable mediación textual de caucheros, funcionarios, misioneros, militares, exploradores, naturalistas, etc., es el proceso que queremos abordar. Sin embargo, también es cierto que la industria gomífera no se detuvo por completo en la región amazónica luego de la caída general de 1912, sino que siguió operando regionalmente a nivel local durante varias décadas, teniendo una presencia más o menos constante e incluso algunos repuntes generalizados, como en la Segunda Guerra mundial. Es así que, si se deja de lado el foco espacio-temporal en el período del auge cauchero boliviano, y se analizan comparativamente los desarrollos locales de la industria durante el siglo xx, se encontrará que numerosos grupos indígenas se involucraron de forma más o menos activa en la maquinaria gomífera y generaron al hacerlo un corpus creciente de relatos a partir de sus experiencias (p. ej. Piccoli 1993; Alonso y Ardaiza 2008; Tabo Amapo 2008; Piedrafita Iglesias 2010; Córdoba 2008, 2012b; Paredes Pando 2013; Camargo y Villar 2013). El análisis comparado de estas memorias individuales y colectivas es un tema ciertamente crucial, pero por obvias razones de recorte temático, diacrónico e incluso de espacio no podemos emprenderlo en esta ocasión.
} 
influir ni echado a perder por el barullo de la goma sino que seguían viviendo su existencia soñadora en la selva, sin preocuparse, modestos y contentos, como si el tiempo y el cambio no existieran. (Leutenegger 1940, p. 312)

\section{Barbarie en plural}

El estudio comparado del imaginario cauchero sugiere que las categorizaciones de la alteridad étnica no son objetivas, traslúcidas, directas, sino que son construcciones ideológicas que ganan densidad simbólica con el correr del tiempo, a medida que se autonomizan y se liberan de su contexto de producción. Imágenes que toman sentido al ser fraguadas, circuladas, negociadas, reinventadas según las diferentes racionalidades e intereses de cada contexto (Chaumeil 2009). En el caso particular del boom cauchero en Bolivia, el modelado ideológico del indígena amazónico supone desde el vamos una mediación textual ineludible; en este sentido, hay que preguntarse hasta qué punto vale la pena suponer que, con todas sus idiosincrasias y preconceptos, los testimonios de caucheros, funcionarios, misioneros, militares, exploradores, naturalistas, etc. son « distorsiones » de una imagen « en sí », originaria, auténtica, o si se trata más bien de discursos productivos, en el sentido de que se nutren de la trama relacional del contacto para generar diferencias e identidades (Pratt 2011).

Más o menos arraigados, más o menos conscientes, intereses económicos, agendas políticas, concepciones de la ciudadanía, disputas fronterizas, ideologías raciales, utopías, moralidades: todos estos factores parecen operar como componentes cruciales de los estereotipos étnicos. Si recapitulamos las imágenes sobre el indígena amazónico que nos legan los cuarenta años del boom cauchero en Bolivia, y pensamos en los juegos de similitudes y contrastes entre la fluidez de la adaptación araona, la diplomacia pintoresca de los chacobos o la violencia sistemática atribuida a los caripunas, es evidente que las representaciones étnicas mutan en función del enunciador o de los contextos, como queda claro en el caso de las disputas limítrofes, que alteran drásticamente la percepción de los caripunas según se privilegie el punto de vista « boliviano » 0 《 brasileño ».

¿Basta entonces, en estas circunstancias, con afirmar que los indígenas del boom cauchero no son todos iguales? Con su énfasis en el discurso republicano del progreso y la civilización, el paradigma oficial sobre la cuestión indígena nos propone una primera gran divisoria de aguas que no es más ni menos que la vieja oposición entre « indios » $\mathrm{y}$ «blancos ». Categorías reductoras, genéricas, que operan como si hubiera bloques sociales homogéneos (cuando sabemos que los araonas combaten con los pacaguaras, los misioneros con los caucheros, los brasileños con los bolivianos, etc.) e incluso actores invariantes (cuando sabemos que los « cavineños » se transforman en « tacanas », o viceversa, y que los « pacaguaras » se convierten en « chacobos »). Entonces, ¿qué « indios » y qué « blancos »? Podemos preguntar, además, según este marco interpretativo, 
dónde ubicar los actores mestizos, protagonistas crecientes de la historia con el correr de las décadas, muchas veces más numerosos que los « indios »o incluso que los «blancos » (Combès 2010, p. 16).

Las fuentes responden al dilema casi intuitivamente. Descomponen el « polo indio » en un segundo nivel de contraste: indígenas « civilizados » (cayubabas, baures, movimas, etc.) versus indígenas « salvajes » 0 《 bárbaros » (araonas, cavineños, chacobos, pacaguaras, caripunas). Por un lado, exponen la inventiva, la flexibilidad estratégica y la capacidad de adaptación de distintos grupos étnicos que se integran exitosamente a la sociedad nacional y gradualmente logran acceder a sus derechos como ciudadanos plenos. Por otro lado, a contramano, silenciados, marginalizados, están los bárbaros. Naturalmente, esta nueva dicotomía entre indígenas « civilizados » $\mathrm{y}$ 《 salvajes », cuyos antiguos avatares son los indios « mansos » $\mathrm{y}$ 《 bravos », « amigos » $\mathrm{y}$ 《 salvajes », « conversos » $\mathrm{y}$ « apóstatas », no tiene nada de novedoso; se entronca, o más bien se retroalimenta, con el discurso misionero que precede a la época del auge cauchero (y aun podría remontarse más allá, si pensamos en diversas categorías genéricas de la alteridad salvaje: « antis », « chunchos », « chiriguanos », « guarayos », etc.). Hay indios e indios, pues, y hay también toda una serie de razones que lo explican - y explican, incluso, que haya muchos más estudios consagrados a los primeros que a los segundos. Porque, en las tierras bajas bolivianas, una cosa son los indígenas que pasan por el tamiz jesuítico y otra aquellos que no. Sabemos que hay epidemias, guerras, relaciones interétnicas, procesos de misionización o articulación con el mercado bien distintos. Por sobre todo, la disciplina misional explica que haya (¿causa o consecuencia?) indígenas con o sin apellidos, más o menos dóciles, más o menos socializados, más o menos sedentarizados y adaptables a las demandas de la fe, la moral, el mercado laboral y la causa republicana. Lo cual implica necesariamente que haya otros grupos que en esos términos no pueden ser definidos más que por la negativa: aquellos que no tienen apellido, pudor, religión, cultura ni capacidad de generar excedentes.

Sea novedad o intensificación sedimentada de un proceso previo, lo notable del discurso cauchero sobre el indígena amazónico es que, cuando comenzamos a observarlos más de cerca, los términos de la fractura entre « mansos » y « bravos » se desdibujan una vez más. Por lagunas en las fuentes, por sesgos de la información o por intereses de los agentes mediadores, sí, pero sobre todo por el hecho de que los mismos atributos que distinguen en bloque a los « civilizados » de los « salvajes » (suciedad, inmoralidad, violencia, antropofagia) reaparecen para diferenciar, en un tercer nivel de oposición, a los mismos « salvajes » entre sí: al menos a unos que podríamos llamar « salvajes más civilizados » (araonas, cavineños) de otros que parecen ser « salvajes menos civilizados » (pacaguaras, chacobos, caripunas). A los bárbaros dóciles de los imposibles: a aquellos que en ciertas circunstancias tal vez lleguen a encarnar el ideal de socialización aceptando las reglas de juego del mercado, el matrimonio 
o el civismo (p. ej. la esposa cavineña de Robuchon, adaptada a la vida social francesa), de aquellos otros que difícilmente puedan traspasar esa barrera (la esposa pacaguara expulsada de la hamaca conyugal por su falta de higiene $)^{20}$.

La salida más directa, naturalmente, sería pedir ayuda a la lingüística o a la etnología. De un lado los tacanas, del otro los panos. Los primeros se involucran de forma directa en la producción cauchera; los segundos lo hacen apenas de forma indirecta con su reproducción. Hay indios y blancos, claro; hay indígenas civilizados y salvajes, también; hay, por fin, salvajes más y menos salvajes. Pero en realidad la introducción de la variable lingüística tampoco alcanza para dirimir el problema. Porque aun así, en un cuarto nivel de discriminación, si nos detenemos por ejemplo en el caso de los panos, las fuentes nos permiten distinguir otra vez entre salvajes más salvajes que son menos salvajes (chacobos), salvajes más salvajes que son más salvajes que ellos (pacaguaras), e incluso otros salvajes más salvajes que son todavía más salvajes (caripunas). Lo absurdo del juego de palabras refleja en cierta forma la inestabilidad relacional del imaginario. Porque lo complejo de este juego de redundancias, al fin y al cabo, es que en la medida en que aproximamos el zoom analítico para abarcar parcialidades, comunidades, familias extensas e individuos se repite lo mismo: « civilización » y « barbarie » se nos presentan como cualidades relativas. En cada nivel del discurso dualista reaparece un segmento más salvaje y otro más civilizado, como si la representación - al menos para este período y para este caso puntual - estuviera forzada a pensar la alteridad en términos relacionales, pero a la vez jerárquicos o al menos contrapuestos. Deberá bastar, por el momento, con la constatación descriptiva de que el imaginario cauchero del indígena amazónico construye sus representaciones de forma relacional, y que los discursos de la alteridad que producen « etnias », « salvajes » e « indígenas » en las fuentes no pueden reducirse en ningún caso a una lógica única, transparente y unívoca. *

* Manuscrit reçu en février 2014, accepté pour publication en novembre 2014.

Agradecemos a Hans Joachim Wirtz, Mily Hecker, Guillermo Rojas, Isabelle Combès, Anna Guiteras Mombiola, David Jabin, Francis Ferrié y Diego Villar por haber colaborado con la elaboración de este trabajo, como así también a los dos evaluadores anónimos del JSA, por sus útiles comentarios y sugerencias.

\section{Referencias citadas}

ACS Archivo Casa Suárez (Guayaramerín)

20. Vale recordar, sin embargo, que al menos en Mojos, desde finales del siglo XVIII, tanto las autoridades seculares como las religiosas procuran promover el mestizaje entre indígenas « bárbaros » (por ejemplo pacaguaras) y « civilizados » (por ejemplo cayubabas) para facilitar el proceso de colonización « licuando » la diferencia de los primeros (Villar et al. 2009: 101). 
Alonso O. Rafael y Rossana Arbaiza G. (eds.)

2008, Papachí ese eja. Misioneros dominicos y huarayos: una historia interrumpida, Centro Cultural José Pío Aza, Lima.

ANÓNIMO

1894, El doctor don Antonio Vaca Díez. Sus antecedentes. Su obra. Sus detractores, Imprenta y Litografía de El Comercio, Cochabamba.

ArauZ Ignacio

1868, « New fluvial outlet for Bolivia », in George Earl Church (ed.), Explorations made in the valley of the river Madeira, from 1749 to 1868, National Bolivian Navigation Company, Londres, p. 189-202.

ARMentia Nicolás

1976, Diario de sus viajes a las tribus comprendidas entre el Beni y el Madre de Dios y en el arroyo Ivon en los años de 1881 y 1882, Instituto Boliviano de Cultura, La Paz [1882].

1885, Exploración oficial mandada efectuar del Madre de Dios en 1884, Imprenta El Nacional, La Paz.

BALdivieso Pastor

1896, Informe que presenta al señor Ministro de Colonización el Intendente de la Delegación nacional en el Noroeste, teniente coronel Pastor Baldivieso. Bolivia, Riberalta, Taller Tipo-Litográfico, La Paz.

Ballivián Manuel y Casto Pinilla

1912, Monografía de la industria de la goma elástica en Bolivia, Dirección General de Estadística y Estudios Geográficos, La Paz.

BALZAN Luigi

2008, A carretón y canoa. La obra del naturalista Luigi Balzan en Bolivia y Paraguay (1885-1893), Clara López Beltrán (ed.), IFEA/IRD/Embajada de Italia/Plural Editores, La Paz [1885-1893].

BARHAM Bradford y Oliver COOMES

1994, « Wild rubber: industrial organisation and the microeconomics of extraction during the Amazon rubber boom (1860-1920) », Journal of Latin American studies, 26 (1), p. 37-72.

BAYO Ciro

1911, El peregrino en Indias. En el corazón de la América del Sur, Librería de los Sucesores de Hernando, Madrid.

Bethell Leslie (ed.)

1991, Historia de América latina. América latina: economía y sociedad, c. 1870-1930, t. 7, Editorial Crítica, Barcelona.

1991, Historia de América latina. América del Sur, c. 1870-1930, t. 10, Editorial Crítica, Barcelona.

BRESSON André

1886, Bolivia, sept années d'explorations, de voyages et de séjours dans l'Amérique australe, prefacio de M. Ferdinand de Lesseps, Challamel Ainé, París. 
Brohan Mickaël y Enrique Herrera

2008, « Prólogo de los editores », in Alfredo Tabo Amapo, El eco de las voces olvidadas. Una auto-etnografía y etnohistoria de los cavineños de la Amazonía boliviana, IWGIA, Copenhague, p. 12-45, 206-280.

Camargo Eliane y Diego Villar (orgs.)

2013, Huni kuin hiwepaunibuki. A história dos Caxinauás por eles mesmos, Serviço Social do Comércio, San Pablo.

Castillo Marius del

1929, El corazón de la América meridional (Bolivia), t. 1, Imprenta Comercial, Barcelona.

Centeno Ricardo y Patricia Fernández O.

1998, Imágenes del auge de la goma, La Papelera, La Paz.

Chaumeil Jean-Pierre

2009, « Guerra de imágenes en el Putumayo (1902-1920) », in Alberto Chirif y Manuel Cornejo Chaparro (eds.), Imaginario e imágenes de la época del caucho: los sucesos del Putumayo, CAAAP/IWGIA/UPC, Lima, p. 37-73.

CoImBRA Juan B.

2010, Siringa. Memorias de un colonizador del Beni, Librería Editorial GUM, La Paz [1946].

Coffaci De Lima Edilene y Lorena Córdoba (eds.)

2011, Os outros dos outros: relações da alteridade na etnologia sudamericana, UFPR, Curitiba.

ComBÈs Isabelle

2010, « ¿Indios y blancos? Hacer (etno)historia en las tierras bajas bolivianas », Boletín americanista, 60, p. 15-32.

CóRdoba Lorena

2012a, « El boom cauchero en la Amazonía boliviana: encuentros y desencuentros con una sociedad indígena (1869-1912)», in Diego Villar y Isabelle Combès (eds.), Las tierras bajas de Bolivia: miradas históricas y antropológicas, Editorial El País (Colección de ciencias sociales, 29), Santa Cruz de la Sierra, p. 125-156.

2012b, « Misioneros-patrones e indígenas-siringueros: el caucho entre los chacobos del Beni (siglo xx) », Boletín americanista, 65, p. 85-106.

2008, Parentesco en femenino: género, alianza y organización social entre los chacobo de la Amazonía boliviana, tesis doctoral, Universidad de Buenos Aires, Buenos Aires.

Chávez SAucedo Medardo

2009, Eldorado boliviano, Fundación NOVA, Santa Cruz de la Sierra [1926].

Craig Neville

1907, Recollections of an ill-fated expedition to the headwaters of the Madeira river in Brazil, J. B. Lippincott Company, Filadelfia/Londres.

ECHEVERri Juan Álvaro

2010, «La suerte de Robuchon », in Eugenio Robuchon, En el Putumayo y sus afluentes, Biblioteca del Gran Cauca, Universidad del Cauca, Lima, p. 19-56. 


\section{EDWARDS Herbert}

1915, « Further frontier work on the Bolivia-Brazil northern boundary », The geographical journal, 45 (5), p. 384-402.

ERIKSON Philippe

1993, « Une nébuleuse compacte: le macro-ensemble pano », L’Homme, 126-128, p. 45-58.

FAwCETT Percy

1954, Exploración Fawcett, Zig-Zag S.A., Santiago de Chile.

FERRIÉ Francis

2014, Renaissance des Leco perdus. Ethnohistoire du piémont bolivien d'Apolobamba à Larecaja, thèse de doctorat, Université Paris Ouest Nanterre La Défense, Nanterre.

FIFER Valerie

1970, « The empire builders: a history of the Bolivian rubber boom and the rise of the house of Suarez », Journal of Latin American studies, 2 (2), p. 113-146.

Gamarra Téllez María del Pilar

2007, Amazonía norte de Bolivia. Economía gomera (1870-1940). Bases económicas de un poder regional. La Casa Suárez, Colegio Nacional de Historiadores de Bolivia/CIMA, La Paz.

GARCÍA JoRdÁn Pilar

2001, Cruz y arado, fusiles y discursos. La construcción de los Orientes en el Perú y Bolivia, 1820-1940, IFEA/IEP, Lima.

Giglioli Enrico

1906, « Appunti sulle condizioni attuali delle tribu indigene dell'alto Madeira e región adiacenti (Brasile e Bolivia). Raccolti dal Dott. Andre Landi », Archivio per l'antropologia e la etnologia, 36, p. 219-228.

Guiteras Mombiola Anna

2012, De los llanos de Mojos a las cachuelas del Beni, 1842-1938, Instituto de Misionología/Editorial Itinerarios, Cochabamba/Archivo y Biblioteca Nacionales de Bolivia, Sucre.

Heath Edwin

1969, « Informe sobre los estudios hechos en el departamento del Beni en los años 18791880-1881 » [1879-1881], Colección de folletos bolivianos de hoy, 4 (20), p. 7-15.

1896, La exploración del río Beni, anotada y traducida por Manuel Ballivián, Imprenta de la Revolución, La Paz.

Herrera Sarmiento Enrique

2011, Multiculturalisme et ethnicite en Amazonie bolivienne. La gestion publique des différences ethniques et l'invention des Indiens Tacana, thèse de doctorat, Université de la Sorbonne Nouvelle, Paris.

Keller LeuZinger Francisco

1875, The Amazon and Madeira rivers. Sketches and descriptions from the note-book of an explorer, Chapman and Hall, Londres. 
Keller Leuzinger José y Francisco Keller Leuzinger

1870, Exploración del río Madera en la parte comprendida entre la cachuela San Antonio y la embocadura del Mamoré por los ingenieros brasileros José y Francisco Keller, Imprenta de la Unión Americana, La Paz.

La gaceta del Norte (Riberalta)

1887, 23 de octubre de 1887.

1887,9 de noviembre de 1887.

1904, 15 de septiembre de 1904.

1906, 15 de junio de 1906.

LEUTENEGGER Ernst

1940, Menschen im Urwald: ein Schweizer erlebt Bolivien, M. S. Metz, Zürich.

Limpias SAUCEDo Manuel

2005, Los gobernadores de Mojos, Prefectura del Departamento del Beni, Trinidad [1942].

Matthews Edward

1875, « Report to the directors of the Madeira and Mamoré Railway Company Limited », in George Earl Church (ed.), Explorations made in the valley of the river Madeira, from 1749 to 1868, Waterlow and Sons, Londres, p. 1-90.

Mariaca Timoteo

1987, « Exploración al río Acre » [1887], Colección de folletos bolivianos de hoy, 3 (19), p. 3-32.

MARKHAM Clements

1883, «The basins of the Amaru-Mayu and the Beni », Proceedings of the Royal geographical society and monthly record of geography, 5 (6), p. 313-327.

MendizÁBAL Santiago

1932, Vicariato apostólico del Beni. Descripción de su territorio y sus misiones, Imprenta Renacimiento, La Paz.

MERCIER Víctor

1981, « Diario de una expedición del Madre de Dios al río Acre » [1894], Colección de folletos bolivianos de hoy, 3, p. 3-16.

NORDENSKIÖLD Erland

2003, Indios y blancos en el Nordeste de Bolivia, APCOB/Plural, La Paz [1922].

2001, Exploraciones y aventuras en Sudamérica, APCOB/Plural, La Paz [1924].

PANDo José Manuel

1897, Viaje a la región de la goma elástica (N.O. de Bolivia), Imprenta El Comercio, Cochabamba.

1892, « Informe que el jefe de la Exploración de los ríos del Norte de Bolivia, eleva al conocimiento del Supremo Gobierno, en cumplimiento del contrato celebrado el 30 de mayo de 1892 », Archivo de La Paz, Fondo José Manuel Pando, 1891-1897, nº 2. 
PARedes PANdo Oscar

2013, Explotación del caucho-shiringa: Brasil-Bolivia-Perú. Economías extractivo-mercantiles en el Alto Acre-Madre de Dios, t. 2, JL Editores, Cuzco.

PeARson Henry

1911, The rubber country of the Amazon. A detailed description of the great rubber industry of the Amazon valley, which comprises the brazilian states of Para, Amazonas and Matto Grosso. The territory of the Acre, the Montana of Peru and Bolivia, and the southern portions of Colombia and Venezuela, The India Rubber World, Nueva York.

Piccoli Jacó

1993, Sociedades tribais e a expansão da economia da borracha na área Jurua-Purus, tese de doutorado, Pontificia Universidade Católica de São Paulo, San Pablo.

Piedrafita Iglesias Marcelo

2010, Os Kaxinawá de Felizardo: correrias, trabalho e civilização no Alto Juruá, Paralelo 15, Brasilia.

PRATT Mary Louise

2011, Ojos imperiales. Literatura de viajes y transculturación, Fondo de Cultura Económica, México.

Quevedo Quintín

1875, « The Madeira and its headwaters », in George Earl Church (ed.), Explorations made in the valley of the river Madeira, from 1749 to 1868, National Bolivian Navigation Company, Londres, p. 167-188.

Quijarro Antonio

1893, Conferencia pronunciada el 18 de junio por el Doctor Antonio Quijarro exponiendo considerandos de la actualidad acerca de los ríos Madre de Dios, Aquiry y Purús, Imprenta El Comercio, La Paz.

RICHARD Nicolas

2013, « Aproximación al problema de los caminos, u odografía, en el Chaco y en la Puna contemporáneos ", in Pablo Sendón y Diego Villar (eds.), Al pie de los Andes. Estudios de etnología, arqueología e historia, Itinerarios/ILAMIS, Cochabamba, p. 47-70.

Ritz Franz

1934, Kautschukjäger im Urwald, Orell Füssli Verlag, Zürich/Leipzig.

Roca José Luis

2001, Economía y sociedad en el Oriente boliviano (Siglos xvi-xx), COTAS, Santa Cruz de la Sierra.

ROYAL GEOGRAPHICAL SOCIETY

1889, " Colonel Labre's explorations in the region between the Beni and Madre de Dios rivers and the Purus », Proceedings of the Royal geographical society and monthly record of geography, 11 (8), p. 496-502. 
SANABria Fernández Hernando

2009, En busca de Eldorado. La colonización del Oriente boliviano, La Hoguera Investigación, Santa Cruz de la Sierra [1958].

SANJINÉS Fernando de

1895, Ligeros apuntes de viaje, La Paz.

TAво AмApo Alfredo

2008, El eco de las voces olvidadas. Una auto-etnografía y etnohistoria de los cavineños de la Amazonía boliviana, IWGIA, Copenhague.

Torres López Ciro

1930, Las maravillosas tierras del Acre (en la floresta amazónica de Bolivia), Talleres del Colegio Don Bosco, La Paz.

VALLVÉ Frederic

2010, The impact of the rubber boom on the indigenous peoples of the bolivian lowlands (1850-1920), tesis doctoral, Georgetown University, Washington.

VAN VALEN Gary

2003, The ventriloquist messiah and his followers: Mojo Indian responses to the rubber boom in eastern Bolivia, 1860-1930, doctoral dissertation, The University of New Mexico, New Mexico.

2013, Indigenous agency in the Amazon. The Mojos in liberal and rubber-boom Boliiva, 1842-1932, The University of Arizona Press, Arizona.

VILlar Diego, Lorena CóRdoba y Isabelle Combès

2009, La reducción imposible. Las expediciones del padre Negrete a los pacaguaras (1795-1800), Nómadas/ILAMIS, Cochabamba.

WEGNER Richard

1936, Zum Sonnentor durch Altes Indianerland, L. C. Wittich, Verlag/Darmstadt.

WeInstern Barbara

1983, The Amazon rubber boom, 1850-1920, Stanford University Press, Stanford. 